\title{
Studies on Urea Cycle Enzyme Levels in the Human Fetal Liver at Different Gestational Ages
}

\author{
M. MUKARRAM ALI BAIG, C. M. HABIBULLAH, M. SWAMY, S. IBRAHIM HASSAN, \\ TAHER-UZ-ZAMAN, QAMAR AYESHA, AND B. GEETHA DEVI \\ Intensive Liver Care Unit, Department of Gastroenterology, Osmania General Hospital, Hyderabad Andhra \\ Pradesh, India 500012
}

\begin{abstract}
Urea cycle enzymes involved in the detoxification of ammonia were studied in liver tissues of 57 male and 49 female fetuses of different age groups ranging from 13 to 36 wk of gestation. Surgical wedge biopsies of liver from 18 male and 12 female adults were used as controls. Significant enzyme activity was found to be present as early as the 13th wk of gestation. As gestational age advanced, enzyme activity gradually increased, reaching about $90 \%$ of the adult activity by the 36th wk of gestation. (Pediatr Res 31: 143-145, 1992)
\end{abstract}

\section{Abbreviations}

CPS, carbamyl phosphate synthetase

OCT, ornithine carbamyl transferase

AS, argininosuccinate synthetase

AL, argininosuccinate lyase

TCA, trichloroacetic acid

In mammals, urea is the main end product of nitrogen metabolism. Approximately $90 \%$ of the total nitrogen excreted by ureotelic animals takes the form of urea (1). The main site of urea metabolism is liver. There are very few reports on urea cycle enzyme estimations in human fetal liver. Because the sample size in humans is very small, meaningful statistical data cannot be derived $(2,3)$. Slemons and Moris (4) reported the presence of urea cycle enzymes in maternal and fetal serum, but not in tissues. Hammet (5) demonstrated high levels of urea cycle enzymes in placenta of toxemic patients. Mandersheid (6) was the first to measure urea from fetal liver tissue using the tissue slicing technique of Krebs and Henseleit (7). Subsequent workers reported urea cycle enzymes and urea levels in fetal tissue, blood, and amniotic fluid of varying gestational age groups (8-13). The difference between urea cycle enzyme levels in rat fetal liver and in human fetal liver was first reported by Raiha and Kretchmer (9). They observed that rat fetal liver has negligible urea cycle enzyme activity. Kennan and Cohen (3) demonstrated urea cycle enzyme activity in human fetal liver at 12 wk of gestation.

Hepatocyte transplantation is emerging as an alternative to orthotopic liver transplantation in the treatment of acute liver failure $(14,15)$. Studies are being carried out to assess the efficacy of hepatocyte transplantation in acute and chronic liver failure. Transplantation of fetal hepatocytes has already been used in the treatment of Fabry's and Gaucher's disease, with results that have stimulated continued research (16). The biology of hepa-

Received February 11, 1991; accepted August 28, 1991

Correspondence and reprint requests: Dr. C. M. Habibullah, Prof. and Head, Department of Gastroenterology, Osmania General Hospital, Afzulgung, Hyderabad-500 012 (A.P.), India.

Supported by a financial grant from the Indian Council of Medical Research, New Delhi. tocytes is also being studied in great depth. The data from these experiments justify the consideration of fetal hepatocyte transplantation in acute liver failure (17). In the present study, urea cycle enzymes were measured in human fetal livers $(n=106)$ starting at 13 wks of gestation. Fetal values for urea cycle enzymes are compared with those of adult human liver tissues used as controls.

\section{MATERIALS AND METHODS}

Fetuses included in the study were collected within $2 \mathrm{~h}$ of abortion after consent was obtained from the parents or guardians. The fetuses were obtained from different maternity hospitals surrounding this research center (Intensive Liver Care Unit, Osmania General Hospital). Fetal samples were derived from spontaneous abortions, still births, and, occasionally, medical termination of pregnancies due to maternal causes. Premature infants near full term who died in the sick nursery were also used for the study after consent was obtained. The adult human liver tissue was obtained from patients undergoing laparotomy for nonliver diseases and was included in the study after consent was obtained. The guardians of the fetuses were informed about the use of fetal livers in the treatment of human patients suffering from acute hepatic failures.

This therapeutic research project was sponsored by the Indian Council of Medical Research, New Delhi. The ethical committee consists of prominent researchers and legal advisers who deliberate about the use of the fetal liver tissue for the treatment of human patients with fulminant hepatic failure.

A total of 106 human fetuses consisting of 57 males and 49 females was included in the study. They were arranged into six gestational age groups: Group I, 13-16 wk; group II, 17-20 wk; group III, 21-24 wk; group IV, 25-28 wk; group V, 29-32 wk; and group VI, 33-36 wk. Liver perfusion was done within $2 \mathrm{~h}$ of abortion by the method of Habibullah et al. (18). Thirty adult patients undergoing laparotomy were used as controls, and wedge biopsies of liver were obtained. The biopsy tissue was immediately chilled in a sterile, dry bottle of $5 \mathrm{~mL}$ capacity kept in an ice box. This tissue was not perfused but was thoroughly washed with the Hank's buffer used in fetal perfusion to remove blood elements. The biopsy tissue was minced before being used for the enzyme estimation. The enzyme estimations were done by the procedures described below.

CPS. CPS was assayed by the method of Levin (19). The liver was homogenized in a solution that contained $0.01 \mathrm{M}$ ATP and $0.01 \mathrm{M} \mathrm{MgSO} 4 \cdot 7 \mathrm{H}_{2} \mathrm{O}$, adjusted to $\mathrm{pH} 6.7$ at $37^{\circ} \mathrm{C}$ with solid $\mathrm{KHCO}_{3}$. This homogenate was diluted $1: 1$ with $0.1 \%$ cetyl ammonium bromide until a final liver concentration of 1:10 was achieved. The preparation was kept cold until use.

Several solutions were required to form the substrate mixture. Solution A contained $0.03 \mathrm{M}$ ATP and $0.03 \mathrm{M} \mathrm{MgSO}_{4} \cdot 7 \mathrm{H}_{2} \mathrm{O}$, adjusted to $\mathrm{pH} 6.7$ with solid $\mathrm{KHCO}_{3}$. Solution B contained 0.04 $\mathrm{M} l$-ornithine monohydrochloride and $0.04 \mathrm{M} \mathrm{N}$-acetyl glutamic 
acid and was adjusted to $\mathrm{pH} 6.0$ with approximately $1 \mathrm{~N} \mathrm{KOH}$ solution, made $0.4 \mathrm{M}$ with a calculated amount of solid ammonium bicarbonate, and adjusted to $\mathrm{pH} 7.5$ with solid $\mathrm{KHCO}_{3}$. The substrate was prepared by mixing two parts solution A with one part solution $\mathrm{B}$, resulting in a $\mathrm{pH}$ of $\sim 7.0$. The substrate mixture was gassed with $\mathrm{CO}_{2}$ just before use until the $\mathrm{pH}$ was $\sim 6.8$ at $37^{\circ} \mathrm{C}$. For the assay, $0.1 \mathrm{~mL}$ of homogenate was mixed with $0.3 \mathrm{~mL}$ of substrate solution in a small tube and incubated at $38^{\circ} \mathrm{C}$ for $20 \mathrm{~min}$. To stop the reaction, $0.2 \mathrm{~mL}$ of $7 \%$ perchloric acid was added, the tube was centrifuged, and $0.25 \mathrm{~mL}$ of $1 \%$ dimethyl glyoxime in $96 \%$ ethanol was added to $0.25 \mathrm{~mL}$ of the supernatant, followed by the addition of $2.5 \mathrm{~mL}$ of acid mixture ( $4 \mathrm{~g}$ of phenazone in a mixture of $76 \mathrm{~mL}$ of concentrated $\mathrm{H}_{2} \mathrm{SO}_{4}$, $11 \mathrm{~mL}$ of concentrated $\mathrm{H}_{3} \mathrm{PO}_{4}$, and $163 \mathrm{~mL}$ of water). After thorough mixing, the tubes were covered with vaccine caps pierced by syringe needles and heated in a bath at $100^{\circ} \mathrm{C}$ in darkness for $20 \mathrm{~min}$. The tubes were then cooled and read at $447 \mathrm{~nm}$. The activity was expressed in $\mu \mathrm{mol}$ of citrulline formed per $\mathrm{h}$ per $\mathrm{g}$ tissue.

$O C T$. OCT was assayed according to the method described by Vaclav and Vera (20). In this method, $0.1 \mathrm{~mL}$ of $1.1 \%$ tissue homogenate was incubated with $0.2 \mathrm{~mL}$ of ornithine glycylglycine buffer $(80 \mathrm{mg}$ of glycylglycine base and $100 \mathrm{mg}$ of $l$-ornithine monohydrochloride, dissolved in $\sim 8 \mathrm{~mL}$ of water, $\mathrm{pH}$ adjusted to 8.0 by $1 \mathrm{~N} \mathrm{NaOH}$ ), along with $0.1 \mathrm{~mL}$ of carbamyl phosphate solution $(12 \mathrm{mg} / \mathrm{mL}$ dissolved in cold, double-distilled water). The tubes were incubated at $37^{\circ} \mathrm{C}$ for $20 \mathrm{~min}$. The control set was deproteinized before incubation by adding $0.1 \mathrm{~mL}$ of $0.45 \%$ phenyl mercuric borate and $0.15 \mathrm{~mL}$ of $10 \%$ TCA. Test reaction was stopped only after incubation. Both control and test samples were centrifuged at $4000 \mathrm{rpm}$. To $0.25 \mathrm{~mL}$ of the supernatant, $0.25 \mathrm{~mL}$ of dimethyl glyoxime and $2.5 \mathrm{~mL}$ of antipyrine in acid mixture were added. The samples were heated for $20 \mathrm{~min}$ in a boiling water bath. After cooling, the enzyme test was read against a blank at $447 \mathrm{~nm}$. The activity was expressed in $\mu \mathrm{mol}$ of citrulline formed per $h$ per $g$ tissue.

$A S$. AS was estimated by the method described by Levin (19) and modified by Sadasivudu and Indira Rao (21). In the estimation of AS, the incubation mixture contained $0.8 \mathrm{~mL}$ of substrate mixture in $0.05 \mathrm{M}$ phosphate buffer ( $\mathrm{pH} 7.3$ ), which contained $0.01 \mathrm{M}$ each of citrulline, aspartic acid, ATP, $\mathrm{MgCl}_{2}$, and arginase $(21 \mathrm{U})$. Reaction started with the addition of 0.5 $\mathrm{mL}$ of $20 \%$ (wt/vol) homogenate (in $0.25 \mathrm{M}$ sucrose). At the end of $1 \mathrm{~h}$ incubation at $37^{\circ} \mathrm{C}, 1.5 \mathrm{~mL}$ of acid mixture (one part concentrated $\mathrm{H}_{2} \mathrm{SO}_{4}$ and three parts concentrated $\mathrm{H}_{3} \mathrm{PO}_{4}$ ) and $0.1 \mathrm{~mL}$ of isonitrosopropiophenone (5\% in absolute alcohol) were added. It was kept in a boiling water bath for $30 \mathrm{~min}$. After cooling the tubes, absorbance was read at $540 \mathrm{~nm}$. Simultane- ously, a urea standard was set up by adding to the standard 0.5 $\mathrm{mL}$ of substrate mixture and $0.5 \mathrm{~mL}$ of water. The color that developed was read at $540 \mathrm{~nm}$. A reagent blank was also set up. Enzyme activity was expressed as $\mu \mathrm{mol}$ of urea formed per $\mathrm{g}$ wet weight of tissue per $\mathrm{h}$.

$A L$. AL was assayed by the method of Levin (19) as described by Sadasivudu and Indira Rao (21). The assay system for AL consisted of $0.3 \mathrm{~mL}$ of $1 \mathrm{M}$ phosphate buffer $(\mathrm{pH} 7.3), 0.6 \mathrm{~mL}$ of argininosuccinate $(6.0 \mathrm{mM}), 0.2 \mathrm{~mL}$ of $10 \%$ (wt/vol) homogenate in $0.25 \mathrm{M}$ sucrose, and $0.1 \mathrm{~mL}$ of arginase $(10.5 \mathrm{U})$. At the end of $1 \mathrm{~h}$ of incubation at $37^{\circ} \mathrm{C}$, the reaction was stopped by the addition of $1.2 \mathrm{~mL}$ of $10 \%$ TCA. Controls were identical, except that TCA was added before incubation. In the supernatant, the urea was estimated by the method of Wybenga et al. (22). The enzyme activity was expressed as $\mu \mathrm{mol}$ of urea formed per $\mathrm{g}$ wet weight of tissue per $\mathrm{h}$.

Arginase. Arginase was assayed by the method of Herzfeld and Raper (23). Tissue was homogenized in a medium consisting of $56 \mathrm{mM}$ imidazole and $56 \mathrm{mM} \mathrm{MnCl}_{2}(\mathrm{pH} 7.4)$. The homogenate was incubated for $10 \mathrm{~min}$ at $50^{\circ} \mathrm{C}$. The activated preparations were centrifuged, and the supernatants were used for measurement of enzyme activity. Enzyme assay was carried out in a total of $0.8 \mathrm{~mL}$ of incubation mixture consisting of $100 \mu \mathrm{mol}$ of $\mathrm{l}$ arginine, $60 \mu \mathrm{mol}$ of glycine buffer (both adjusted to $\mathrm{pH} 9.5$ with $1.0 \mathrm{~N} \mathrm{NaOH}$ ), and $0.1 \mathrm{~mL}$ of $0.1 \%$ (wt/vol) homogenate. After incubation at $37^{\circ} \mathrm{C}$ for $10 \mathrm{~min}$, the reaction was stopped by the addition of $0.5 \mathrm{~mL}$ of $50 \%$ (wt/vol) TCA before incubation. The mixture was centrifuged, and $0.5 \mathrm{~mL}$ of the supernatant was taken for estimation of urea by the method of Wybenga et al. (22). The enzyme activity was expressed as $\mu \mathrm{mol}$ of urea formed per $g$ wet weight of tissue per $h$.

\section{RESULTS}

Table 1 shows the urea cycle enzyme activities in fetal liver tissues of different gestational age groups and in adult liver tissue. All of the urea cycle enzymes were detectable in the human fetus as early as 13 wk of gestational age. OCT, CPS, AS, and AL levels increased as gestational age advanced, reaching $80-90 \%$ of adult activity by $36 \mathrm{wk}$ (Table 2). Arginase also displayed the same trend, but with gradual increase, and reached about $66 \%$ of adult activity by $36 \mathrm{wk}$. No difference in the enzyme activity was observed between males and females.

\section{DISCUSSION}

The direct measurement of urea production in human fetal liver at 3-4 mo of gestation was reported by Mandersheid (6).

Table 1. Urea cycle enzyme activities in human fetal liver tissues in different gestational age groups compared with human adult liver tissues

\begin{tabular}{|c|c|c|c|c|c|c|c|c|}
\hline Group & $\begin{array}{c}\text { Gestational } \\
\text { age (wk) }\end{array}$ & Sex & $n$ & CPS* & OCT* & $\mathrm{AS} \dagger$ & $\mathrm{AL} \dagger$ & Arginase $\dagger$ \\
\hline \multirow[t]{2}{*}{ I } & $13-16$ & M & 10 & $130.8 \pm 34.3$ & $1125.6 \pm 239.4$ & $47.8 \pm 8.2$ & $86.8 \pm 14.0$ & $20138.0 \pm 3271.5$ \\
\hline & & $\mathrm{F}$ & 7 & $142.2 \pm 18.2$ & $1156.8 \pm 219.7$ & $45.5 \pm 3.06$ & $81.7 \pm 10.9$ & $23728.5 \pm 3825.7$ \\
\hline \multirow[t]{2}{*}{ II } & $17-20$ & M & 13 & $159.2 \pm 34.2$ & $1638.0 \pm 225.7$ & $53.7 \pm 5.9$ & $99.5 \pm 9.40$ & $29364.7 \pm 5714.3$ \\
\hline & & $\mathrm{F}$ & 9 & $188.8 \pm 22.4$ & $1676.6 \pm 167.2$ & $56.2 \pm 10.5$ & $115.2 \pm 16.5$ & $34752.2 \pm 3784.8$ \\
\hline \multirow[t]{2}{*}{ III } & $21-24$ & M & 10 & $184.0 \pm 27.2$ & $2306.8 \pm 123.4$ & $55.1 \pm 4.0$ & $109.4 \pm 13.2$ & $31702.0 \pm 3255.14$ \\
\hline & & $\mathrm{F}$ & 9 & $194.8 \pm 29.8$ & $2333.3 \pm 138.4$ & $57.4 \pm 3.9$ & $123.1 \pm 15.8$ & $33400.0 \pm 3400.7$ \\
\hline \multirow[t]{2}{*}{ IV } & $25-28$ & $\mathrm{M}$ & 10 & $198.8 \pm 19.0$ & $2540.2 \pm 229.5$ & $64.8 \pm 10.6$ & $144.6 \pm 23.2$ & $42288.0 \pm 2994.7$ \\
\hline & & $\mathrm{F}$ & 8 & $197.7 \pm 13.6$ & $2565.0 \pm 299.8$ & $65.3 \pm 7.4$ & $147.2 \pm 26.1$ & $43922.5 \pm 4551.2$ \\
\hline \multirow[t]{2}{*}{$\mathrm{V}$} & $29-32$ & $\mathrm{M}$ & 9 & $222.4 \pm 12.8$ & $3295.5 \pm 331.0$ & $66.7 \pm 8.4$ & $171.1 \pm 28.5$ & $47888.8 \pm 3212.0$ \\
\hline & & $\mathrm{F}$ & 9 & $210.4 \pm 28.4$ & $3491.3 \pm 357.6$ & $75.8 \pm 13.8$ & $156.0 \pm 32.6$ & $48601.1 \pm 4118.3$ \\
\hline \multirow[t]{2}{*}{ VI } & $33-36$ & $\mathrm{M}$ & 5 & $236.4 \pm 12.4$ & $4069.2 \pm 415.5$ & $71.4 \pm 5.8$ & $181.6 \pm 28.3$ & $50474.0 \pm 4476.8$ \\
\hline & & $\mathrm{F}$ & 7 & $212.0 \pm 13.3$ & $3957.4 \pm 238.6$ & $70.5 \pm 8.6$ & $193.1 \pm 15.9$ & $53338.5 \pm 4280.0$ \\
\hline \multirow[t]{2}{*}{ Adult } & & M & 18 & $276.6 \pm 27.2$ & $5301.3 \pm 764.9$ & $88.2 \pm 9.1$ & $218.0 \pm 24.3$ & $77926.3 \pm 13398.1$ \\
\hline & & $\mathrm{F}$ & 12 & $234.5 \pm 21.0$ & $5035.0 \pm 1016.8$ & $85.16 \pm 8.97$ & $205.8 \pm 17.0$ & $80330.6 \pm 4643$ \\
\hline
\end{tabular}

* In $\mu \mathrm{mol}$ of citrulline/g tissue/h.

$\dagger$ In $\mu \mathrm{mol}$ of urea/g tissue/h. 
Table 2. Urea cycle enzyme activities in human fetal liver tissues of different gestational ages expressed as percentage of adult normal human liver activity

\begin{tabular}{llrcrrc}
\hline $\begin{array}{c}\text { Gestational age } \\
\text { group (wk) }\end{array}$ & Sex & CPS & OCT & AS & AL & Arginase \\
\hline I (13-16) & M & 47 & 21 & 53 & 39 & 25 \\
& F & 60 & 23 & 53 & 39 & 29 \\
II (19-20) & M & 57 & 30 & 60 & 45 & 37 \\
& F & 80 & 33 & 65 & 56 & 43 \\
III (21-24) & M & 66 & 43 & 62 & 57 & 40 \\
& F & 82 & 46 & 67 & 67 & 41 \\
IV (25-28) & M & 71 & 47 & 73 & 66 & 54 \\
& F & 84 & 50 & 76 & 71 & 54.5 \\
V (29-32) & M & 80 & 62 & 75 & 78 & 61 \\
& F & 89 & 69 & 89 & 75 & 60.5 \\
VI (33-36) & M & 85 & 76 & 80 & 83 & 64.5 \\
& F & 90 & 78.5 & 82.5 & 93 & 66 \\
Adults & M & 100 & 100 & 100 & 100 & 100 \\
& F & 100 & 100 & 100 & 100 & 100 \\
\hline
\end{tabular}

Kennan and Cohen (3) assayed AS in three human fetal livers of 12,20 , and 40 wk gestation and in two adult livers. They observed AS activity in fetuses of 12 wk gestation. Later, the urea cycle enzyme levels in five human fetal livers of $16-20 \mathrm{wk}$ gestation were studied by Raiha and Suinkonen (11). They noted significant enzyme activity even at $12 \mathrm{wk}$ of gestation. They hypothesized that the enzyme levels in fetal and newborn livers may be lower than those in the adult, but the data are insufficient for conclusions about enzyme development and are also incomplete for comparison of enzymes at different gestational ages. The sample size is not large enough to allow definitive conclusions. Finally, these studies did not use fetal liver perfusion, which was used in our study to avoid measurement of specific enzymes in contaminating blood elements.

The results of this study demonstrate the presence of significant activity for all five urea cycle enzymes in the human fetus as early as $13 \mathrm{wk}$ of gestation. Furthermore, these enzymes gradually increase during fetal life to reach about $90 \%$ of the adult activity by $36 \mathrm{wk}$ gestation. Sex of the fetus does not make any significant difference in the level of urea cycle enzyme in fetal livers of comparable age. From this study, it is evident that fetal hepatocytes have the ability to synthesize urea and detoxify ammonia from an early period of gestation.

Acknowledgment. The authors thank Dr. Sundari Krishna, superintendent of the Government Maternity Hospital, Ameer- bagh, Hyderabad, and her team for cooperation in the collection of fetuses used in this study.

\section{REFERENCES}

1. Swamy M 1984 Urea cycle enzyme and ornithine- $\omega$-amino transferase in brain myocardium and in lens. Doctoral thesis, Osmania University, Hyderabad, A.P., India

2. Raiha NCR 1976 Development changes in urea cycle enzymes in mammalian liver. In: Grisolia S, Baguena R, Mayor F (eds) The Urea Cycle. John Wiley \& Sons, New York, pp 261-272

3. Kennan AL, Cohen PP 1961 Ammonia detoxication in liver from humans. Proc Soc Exp Biol Med 106:170-173

4. Slemons JM, Moris WH 1961 Urea cycle enzymes in maternal and fetal serum. Bull Johns Hopkins Hosp 27:343-350

5. Hammet FS 1981 Urea cycle enzymes in toxaemic patients. J Biol Chem $33: 381-385$

6. Mandersheid $\mathrm{H} 1933$ Uber die Harnst of bill dung beiden wirbeltieren. Biochemistry 263:245-249

7. Krebs HA, Henseleit K 1932 Untersuchungen uber die Haonstoffbildung in Tier Korper. Hoppe-Seylers Z Physiol Chem 210:33-41

8. Freidberg $\vee 1955$ Untersuchungen uber die fetale urobildung. Gynaecologia 140:34-35

9. Raiha NCR, Kretchmer N 1965 Urea biosynthesis during development of the mammal. J Pediatr 67:950-954

10. Illocrova $\mathrm{H} 1966$ Activity of urea cycle enzymes in the liver and urea excretion in the rat during development. Biol Neonate 9:197-202

11. Raiha NCR, Suinkonen J 1968 Development of urea synthesizing enzymes in human liver. Acta Paediat Scand 57:121-124

12. Kekomaki M, Seppala M, Ehnholm C, Schwartz AL, Raivio K 1971 Perfusion of isolated human fetal liver; synthesis and release of alpha feto-protein and albumin. Int J Cancer 8:250-258

13. Tesh ES, Lau YK, Ambros A, Ratman SS 1973 Amniotic fluid creatinine, uric acid and urea as indices of gestational age. Acta Obstet Gynecol Scand $52: 323-326$

14. Kuster GGR, Woods JE 1972 Auxiliary liver transplantation in the dog as temporary support in acute fulminating hepatic necrosis. Ann Surg 176:732735

15. Diaz A, Ricco JB, Franco D 1977 Temporary liver transplantation in acute liver failure. Arch Surg 112:74-78

16. Tourine JL, Roncarolo MG, Margeglia GL 1985 Fetal liver transplantation in immunodeficiencies and inborn errors of metabolism. In: Gale RP, Tourine JL, Lucarelli G (eds) Fetal Liver Transplantation. Alan R Liss, New York, p 299

17. Demetriou AA, Whiting J, Levenson SM 1986 New method of hepatocyte transplantation and liver support. Ann Surg 204:259-270

18. Habibullah CM, Ibrahim Hassan S, Ayesha Q, Taher-uz-Zaman, Mukarram Ali Baig M, Geetha Devi G 1990 Fetal liver perfusion: a new approach. Surg Res Commun 8:87-90

19. Levin B 1971 Methods for the assay of enzymes of the urea cycle. In: Bodansky $\mathrm{O}$, Latner AL (eds) Advances in Clinical Chemistry, Vol 14. Academic Press, New York, pp 81-86

20. Vaclav K, Vera V 1964 On the determination of ornithine-carbamyl transferase activity. Clin Chim Acta 9:95-96

21. Sadasivudu B, Indira Rao T 1976 Studies on functional and metabolic role of urea cycle intermediates in brain. J Neurochem 27:785-794

22. Wybenga DR, Digiorgio J, Pileggi VJ 1971 Manual and automated method for urea nitrogen measurement in whole serum. Clin Chem 17:891-895

23. Herzfeld A, Raper SM 1976 The heterogeneity of arginase in rat tissues. Biochem J 153:469-478 